\title{
JOURNAL OF EDUCATION AND TEACHING LEARNING
}

Journal of Education and Teaching Learning, 2019

Vol. 1, No. 1, 24-29

\begin{abstract}
MENINGKATKAN PRESTASI BELAJAR SISWA MELALUI METODE ROLE PLAYING DALAM PEMBELAJARAN SENI BUDAYA DI KELAS VII-5 SMP NEGERI 1 PATUMBAK
\end{abstract}

Demi Rosmaulina Sinaga

SMP Negeri 1 Patumbak

\begin{abstract}
ABSTRAK
Tujuan penelitian untuk meningkatkan prestasi belajar siswa dalarn pembelajaran Seni Budaya di kelas VII-5 SMP Negeri 1 Patumbak T.P. 2015/2016. Manfaat penelitian: (1).Bagi siswa diharapkan dapat meningkatkan prestasi belajar. (2). Bagi guru, diharapkan dapat meningkatkan kualitas pengajaran. (3). Bagi sekolah, diharapkan dapat meningkatkan ha1 i tas pendidikan Prosedur penelitian terdri dari dua siklus diawali dengan tahapan 4 perencanaan, pelaksanaan, observasi dan retleksi. Berdasarkan temuan hasil penelitian dapat ditarikkesimpulan sebagai berikut: (l).Telah terjah peningkatan prestasi belajar siswa dengan penerapan Metode Role Playing dalarn pembelajaran Seni Budaya di Kelas VII-5 SMP Negeri 1 Patumbak T.P. 2015/2016, hal ini dibuktikan dengan peningkatan Nilai dan 66,67 pada Siklus I menjadi Nilai 76,42 pada siklus 11. (2).Telah terjadi peningkatan aktivitas 'belajar siswa dengan penerapan Metode Role Playing dalam pembelajaran Seni Budaya di Kelas VII-5 SMP Negeri 1 Patumbak T.P. 2015/2016, ha1 ini dibuktikan dengan ratarata aktivitas belajar siswa dalam Aspek Kejasarna meningkat dari 16,9 pada siklus I menjadi 18,9 pada siklus II; dalam Aspek Kesungguhan meningkat dari 16,02 pada siklus I menjadi 19,07 pada siklus II; dalam Aspek Keberanian meningkat dari 17,42 pada siklus I menjadi 18,57 pada siklus II; dalam Aspek Perhatian meningkat dan 16,30 pada siklus I menjadi 19,82 pada siklus II. Untuk memperoleh hasil belajar Seni Budaya yang lebih optimal dengan menggunakan Metode Role Playing, penulis menyarankan kepada guru-guru untuk menerapkan Metode Role Playing dalam pelajaran Seni Budaya dan kepada Pemerintah Kabupaten Deli Serdang Dinas Pendidikan agar mengalokasikan dana untuk penelitian tindakan kelas bagi guru-guru.
\end{abstract}

Kata Kunci: Prestasi Belajar, Metode Role Playing 


\section{PENDAHULUAN}

Berdasarkan pengarnatan penulis selarna bertahun-tahun sebagai guru Seni Budaya di kelas VII-5 SMP Negeri I Patumbak, pernbelajaran Seni Budaya memiliki kecenderungan yang ditandai dengan kondisi yang selalu pasif, motivasi belajar siswa sangat rendah dan interaksi antara siswa dengan siswa maupun antara siswa dengan guru sangat rendah. Aktivitas pernbelajaran urnurnnya Didominasi oleh guru dan hasil belajar siswa tidak rnernuaskan. Padahal, Seni Budaya merupakan salah satu mata pelajaran yang bermanfaat untuk menciptakan manusia yang berkualitas. Dalam pembelajaran Seni Budaya seharusnya guru harus mampu menerapkan metode pernbelajaran yang tepat yang dapat melibatkan siswa seoptimal mungkin baik secara intelektual maupun emosional, karena pernbelajaran Seni Budaya menekankan pada pengalaman belajar. Pada kenyataannya, keberhasilan pembelajaran dipengaruhi oleh beberapa faktor antara lain faktor guru $\mathrm{dm}$ siswa. Guru yang profesional seharusnya selalu mengadakan introspeksi diri dan evaluasi atas kineja (perfomnce). Tidak puas kalau siswa atau anak didiknya tidak behasil menjadi siswa yang berprestasi.

Guru yang profesional adalah guru yang terbuka menerirna kritikan dan masukan demi kernajuan atau prestasi siswa yang diasuhnya. Prestasi belajar siswa sering tidak dapat rneningkat sekalipun guru telah berusaha maksimal menyampaikan dan menjelaskan bahan pelajaran kepada siswa.

Kepada anak didik yang cenderung berpikir konkrit dan penmaan bahasa ynng masih terbatas guru tidak boleh memaksakan diri di dalarn proses belajar mengajar menggunakan metode ceramah saja Karena belum tentu siswa atau kak didik dapat memahami bahan pelajaran yang disarnpaiknn secara verbal karena kemampuan penguasaan bahasa yang msih terbatas dan siswa atau anak didik. Oleh karena itu sebaiknya guru hams menggunakan metode yang tepat untuk menyampai kan bahan pelajaran.

Pemanfaatan Metode Role Playing merupakan strategi penyampaian materi yang mampu menciptakan suasana kelas menjad aktif, kreatif, efektif dan menyenangkan sehingga respon siswa dalam proses pembelajaran sangat tinggi. Apabila guru berhasil menciptakan suasana yang menyebabkan siswa termotivasi aktif dalam belajar akan memungkinkan terjadi peningkatan hail belajar. 


\section{METODE PENELITIAN}

Penelitian direncanakan selarna tiga bulan dimulai tanggal 1 Februari sampai dengan 30 April 2016. Penelitian ini dilakukan di SMP Negen 1 Patumbak dengan alasan peneliti bertugas sebagai guru Seni Budaya di sekolah tersebut. Subjek penelitian adalah siswa Kelas VII-5 SMP Negen 1 Patumbak dengan jumlah siswa 40 orang. Sumber data adalah siswa Kelas VII-5 SMP Negeri 1 Paturnbak clan guru-guru yang bertugas di sekolah tersebut. Penelitian ini dilakukan dengan menggunaknn metode penelitian tindakan kelas terdiri dari 2 siklus. Pengarnatan dilakukan terhadap aktivitas siswa dan guru selana proses pembelajaran Sebelum penelitian dilakukan, peneliti mengadakan diskusi dengan pengamat tentang teknis pelaksanaan pengamatan. Diskusi juga dilakukan setelah pengamatan selesai untuk mengetahui kelebihan-kelebihan dan kekurangankekurangan proses pembelajaran dengan Mefode Role Pluyrng. Pada akhir pembelajaran peneliti melakukan evaluasi terhadap siswa. Semua data yang terkumpul dari hasil pengamat evaluasi, dan diskusi analisis dan dideskripsikan secara objektif sehingga diketahui aspek kelemahan dan aspek kekerhasilan penggunaan Merode Role Playing dalam pembelajaran Seni Budaya. Berdasarkan aspek kelemahan tersebut peneliti rnelakukan perbaikan pada siklus berikutnya sehingga tercapai prestasi belajar yang optimal melalui penerapan Metode Role Playing dalarn pembelajaran Seni Budaya.

\section{HASIL DAN PEMBAHASAN}

\section{Hasil}

\section{Siklus I}

Dari 40 orang siswa, ratarata nilai Aspek Kerjasama adalah 16,92; rata-rata nilai Aspek Kesungguhan adalah 16,02; rata-rata nilai Aspek Keberanian adalah 17,42; dan ratarata nilai Aspek Perhatian adalah 16,3. Total nilai aktivitas belajar siswa baru mencapai nilai rata-rata 66,67, dengan demikian nilai aktivitas belajar siswa pada siklus I dengan penerapan Metode Role Playing masih memerlukan perbaikan. Untuk memperbaiki kondisi ini peneliti melakukan tindakan pada siklus II.

\section{Refleksi}

Analisis terhadap hasil pengarnatan, catatan guru,dan simpulan hasil evaluasi, dijadikan bahan untuk menentukan tindakan selanjutnya, terutama yang berkaitan dengan masih rendahnya perolehan nilai hasil belajar yang diperoleh siswa. 
Tindakan refleksi difokuskan kepada perbaikan memotivasi guru dan siswa yang dilakukan selama siklus I. Setelah melakukan kolaborasi antara observer dengan guru, maka diperoleh hasil refleksi sebagai berikut:

1) Aspek keberhasilan .

a) Sebagian besar siswa lebih tertarik dan termotivasi untuk belajar dengan penerapan Metode Role Playing.

b) Pembelajaran dengan penera pan Metode Role Playing memudahkan mereka memaharni materi pelajaran.

c) Sebagian besar siswa telah mengetahui langkah-langkah atau prosedur pembelajaran dengan penerapan Metode Role Playing.

2) Aspek kelemahan

a) Aktivitas guru dalam pembelajaran belum sesuai dengan penerapan Merode Role Playing.

b) Keterlibatan siswa dalam kelompok masih rendah.

c) Hasil kerja kelompok masih belum sempurna.

d) Masih ditemukannya perilaku yang tidak relevan dengan aktivitas pembelajaran atau KBM.

e) Perlu ditingkatkan motivasi dan bimbingan terhadap siswa agar mampu bekerjasama dalam satu kelompok

\section{Siklus II}

Dari 40 orang siswa, rata-rata nilai Aspek Kerjasama ada!ah 18,95; rata-rata ni!ai Aspek Kesungguhan adalah 19,07; rata-rata nilai Aspek Keberanian adalah 18,57; dan ratarata nilai Aspek Perhatian adalah 19,82. Berdasarkan data pada tabel diatas dapat kita lihat bahwa total nilai aktivitas belajar siswa Kelas VII-5 SMP Negeri 1 Patumbak telah meningkat mencapai nilai mta-rata 76,42. Dengan demikian Penelitian Tindakan Kelas dengan penerapan Mefode Role Pluying berhasil meningkatkan prestasi belajar siswa karena indikator kinerja yang ditetapkan yaitu rata-mta nilai $\mathrm{KKM}=70$ telah tercapai.

\section{Pembahasan}

Analisis terhadap hasil pengamatan, catatan guru, dan simpulan angket respon siswa, menunjukkan bahwa pada siklus ke II telah tejadi perbaikan aktivitas guru dan siswa. Hasil penelitian dapat digambarkan sebagm berikut: Aspek keberhasilan

a. Sebagian besar siswa Kelas VII-5 SMP Negen 1 Patumbak tertarik dan termotivasi belajar dengan Merode Role Playing. 
b. Pernbelajaran dengan Merode Role Playing memudahkan siswa memahami materi pelajaran.

c. Sebagan besar siswa Kelas VII-5 SMP Negen 1 Patumbak telah mengetahui langkahlangkah atau prosedur pembelajaran dengan Merode Role Playing.

d. Aktivitas guru dalam pembelajaran sudah sesuai dengan rencana Merode Role Playing.

e. Semua siswa sudah terlibat aktif belajar dalarn kegiatan kelompok.

f. Hasil kerja kelompok semakin sempurna.

g. Didalarn kerja kelompok tidak ada lag perilaku yang tidak relevan dengan aktivitas pembelajaran sehingga telah terjadi peningkatan hasil belajar siswa secara kelompok. Peningkatan kemampuan ini tercermin dari nilai yang diperoleh oleh kelompok sampel yang menunjukkan nilai telah berada diatas standar ketuntasan belajar minimal atau KKM ynitu 70. Pada Siklus II ini hampir tidak ada lagi aspek kelemahan yang ditemukan.

Berdasarkan kesimpulan atau analisis tentang data antar Siklus yang diperoleh selama Penelitian Tindakan dapat djelaskan bahwa rata-rata Aktivitas Belajar Siswa dalam Aspek Kerjasama meningkatkan dari 16,9 pada siklus menjadi 18,95 pada siklus II; dalam Aspek Kesungguhan meningkat dari 16,02 pada siklus I menjadi 19,07 pada siklus II; dalam Aspek Keberanian meningkat dari 17,42 pada siklus I menjadi 18,82 pada siklus II ; dalam Aspek perhatian meningkat dari 16,3 pada siklus I menjadi 19,82 pada siklus II; Berarti Penelitian Tindakan Kelas dengan penerapan Metode Role Playing telah berhasil meningkatkan Aktivitas Belajar Siswa dari Nilai 66,67 pada Siklus I menjadi Nilai 76,42 pada siklus II. Dengan demikian indikator Kinerja yang ditetapkan yaitu rata-rata nilai ketuntasan minimal (KKM) -70 telah tercapai.

\section{KESMPULAN}

Dari deskripsi data hail dan data proses pembelajaran pada setiap siklus dapat di simpulkan bahwa:

1. Telah terjadi peningkatan prestasi belajar siswa dengan penerapan Metode Role Playing dalam pembelajaran Seni Budaya di Kelas VII-5 SMP Negeri 1 Patumbak T.P. 2015/2016, hal ini dibuktikan dengan peningkatan Nilai dari 66,67 pada Siklus I menjadi Nilai 76,42 pada siklus II. 
2. Telah terjadi peningkatan aktivitas belajar siswa dengan penerapan Metode Role Playing dalam pembelajaran Seni Budaya di Kelas VII-5 SMP Negeri 1 Paturnbak T.P. 2015/2016, ha1 ini dibuktikan dengan rata-rata aktivitas belajar siswa dalam Aspek Kejasama meningkat dari 16,9 pada siklus I menjadi 18,9 pada siklus iI; dalam Aspek Kesungguhan meningkat dari 16,02 pada siklus I menjadi 19,07 pada siklus II; dalam Aspek Keberanian meningkat dari 17,42 pada siklus I menjadi 18,57 pada siklus II; dalam Aspek Perhatian meningkat dari 16,30 pada siklus I menjadi 19,82 pada siklus II.

\section{DAFTAR PUSTAKA}

Anang, Prasetyo. 2001 . Metode Role Playing (Jntuk bfeningkatkan Hasil BelajarSiswa Keltzs 11 SLTP N 3 Lhryono Gresik. Buletin Pelangi Pendidikan. Edisi IV Tahun II.

Djamarah dan Aswan h n . 2002. Strategi Belajar Mengajar. Jakarta: Rineka Cipta.

E. Mu1 yasa 2005. Menjadi Guru Pro fesionoi Menc;ptakan Pembelajaran Kreatif dan Menyenangkan Bandung: Remaja Rosdakqa Offset.

Hamalik, Oemar .200 1. Kurikulwn dun Pembeiujaran. Bandung: Bumi Aksara.

Poerwdarminta, WJS. 1966. Karnus Urnum B a h a Indonesia. Jakarta: Balai Pustaka.

Sanjaya W-.2 006. Strategi Pembelajaran. Jakarta: Kencana Prenada Meda

Nana, Sudjana 2009. Dasar-Dasar Proses Belajar Mengajar. Bandung : Sinar Baru Algesindo.

Sujanto, Agus. 198 1. Psikologi Umuin Jakarta: Aksara Baru.

Winkel. 1987. Psikologi Pengajaran. Jakarta: Grasindo. 